\title{
Experimental Behavior of Post-tensioned Industrialised Building System Blockwork Column
}

\author{
Murtada Sadah Mohsin ${ }^{1}$, Abdul Kadir Marsono ${ }^{2}$ \\ ${ }^{I}$ (Faculty of Civil Engineering, UniversitiTeknologi Malaysia, 81310 UTM Skudai, Malaysia) \\ 2(Associate Professor, Faculty of Civil Engineering, UniversitiTeknologi Malaysia, 81310 UTM Skudai, \\ Malaysia)
}

\begin{abstract}
Precast technology grows rapidly around the world. One of the frequent topic discussions now is the concrete precast block that can flexibility assemble to form a house quickly. In this topic the test consists of Tshape and L-shape and square shape are used to form columns. The blocks was designed in a way which that it can lock to each other and can form a columns. In this research, a test was carried out to determine the behavior of the columns in nonlinear state at various post-tension forces by applying 4 cyclic loads. The posttensioning effect on the column behavior was better and lateral displacement reduced in IBS block work system.
\end{abstract}

Keywords: Industrialized Building System (IBS); Block work system; Interlocking component; Lateral displacement

\section{Introduction}

Industrialized building system (IBS) is a system or construction technique where the components such as beam, wall, column, slab and facade of finishes was fabricated in a controlled factory quality and mass produced. With this approach, components of the building are manufactured off-site (in modules) and brought on to construction project to be assembled [1]. The standardization of elements and fittings of houses will ultimately lead construction project with an increase of efficiency, better quality and less wastage of time and materials [2]. Most importantly it will provide overall lower development cost of buildings [3]. The appropriate cost structure is important as an affordable housing can be built to support the government's initiatives on affordable housing schemes [4].

This project was to construct a blocks of $\mathrm{T}$ shape, $\mathrm{L}$ shape, square shape and rectangular shape as a part of IBS blockwork column system with a post-tension anchor in the laboratory to conduct a test on two units of IBS blockwork system columns which built by using the same design but loaded in two different directions to study the influence of lateral load, vertical post-tension force and blocks interlocking on the columns behavior. The lateral load is applied with 4 cycles of loads and the behavior of columns was conducted by made the relationship between lateral and vertical displacement with the vertical post-tension force and lateral loads.

Post-tensioning system used in this project because it is allows longer clear spans, thinner slabs, fewer beams and more slender elements [5]. Post-tensioning offers the additional advantage that the prestress across the joints between precast elements provides sufficient clamping force to transfer shear in friction and use in moment-resisting frames consist of columns and beams to resist moments and shears from lateral and gravity loads in seismic areas [5].

In this research, a scaled laboratory test was performed on (IBS) blockwork system of columns. The columns consists of a small block which connected together by clamping system of vertical bolts and nuts [5]. The columns are prepared and tested at civil engineering laboratory of universititeknologimalaysia (UTM). The laboratory testing verify the lateral and vertical displacement due to post-tension force at four cyclic lateral loads on two models, similar model except at two different directions of loading and determine the lateral and vertical displacement and lateral load relationship.

\subsection{Materials Properties}

\section{Experimental Details}

The posttension steel $5.061 \mathrm{~mm}$ used with a pre-loading $2.17 \mathrm{KN}$, which represent $60 \%$ of tensile strength force $(3.62 \mathrm{KN})$. In this research, a self-compact concrete with density of $2400 \mathrm{~kg} / \mathrm{m} 3$ was designed according standard stated in European code 2 [8].Based on the mix design shown in Table 1, the obtained concrete modulus of elasticity at 7,28 days and at the day of test was $18.5,29$, and $33.4 \mathrm{MPa}$.

Table 1: Mixture of concrete

\begin{tabular}{|l|l|l|l|l|}
\hline $\begin{array}{l}\text { Water / Cement } \\
\text { ratio }\end{array}$ & $\begin{array}{l}\text { Cement } \\
(\mathbf{k g} / \mathbf{m 3})\end{array}$ & $\begin{array}{l}\text { Water } \\
(\mathbf{k g} / \mathbf{m 3})\end{array}$ & $\begin{array}{l}\text { Fine Aggregate } \\
(\mathrm{kg} / \mathbf{m 3})\end{array}$ & $\begin{array}{l}\text { Coarse Aggregate } \\
(\mathrm{kg} / \mathbf{m 3})\end{array}$ \\
\hline 0.42 & 468 & 234 & 844 & 799 \\
\hline
\end{tabular}




\subsection{Experiments on Interlocking Block Work System IBS Columns}

Two columns consisting of 56 units of precast IBS block are assembled as in Figure 1. Both columns are tested individually for lateral load in parallel and normal directions.

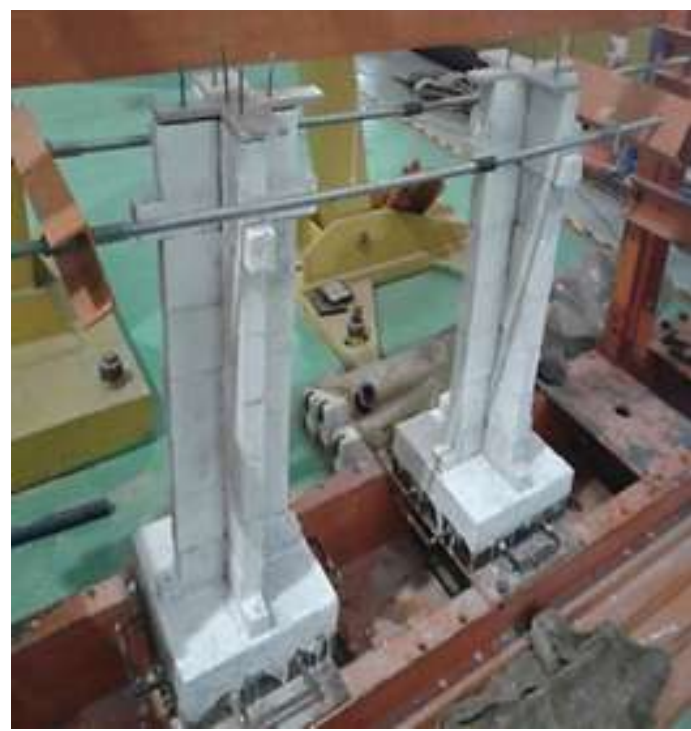

Figure 1: Columns Model 1 and 2

\subsection{Specimens Preparation and Casting Procedure}

The preparation of formwork and reinforcement are carried out 1:5 scale for the blocks which designed previously [9]. The metal pipes with diameter $10 \mathrm{~mm}$ for post-tensioned void preparation as shown in the Figure 2. Prior to casting work, the inner part of the formworks is brush with temper formwork paint to facilitate the formwork stripping after the precast blocks shaping. All blocks have a similar thickness of $40 \mathrm{~mm}$. The components of this frame IBS blocks work are:
1) $40 \times 100 \times 100 \mathrm{~mm}$ (square shape)
2) $40 \times 100 \times 140 \mathrm{~mm}$ (Rectangular shape)
3) $40 \times 100 \times 140 \mathrm{~mm}(\mathrm{~T}$ shape )
4) $40 \times 140 \times 180 \mathrm{~mm}$ ( T shape )
5) $40 \times 140 \times 140 \mathrm{~mm}$ ( L shape )
6) $40 \times 140 \times 180 \mathrm{~mm}(\mathrm{~L}$ shape $)$
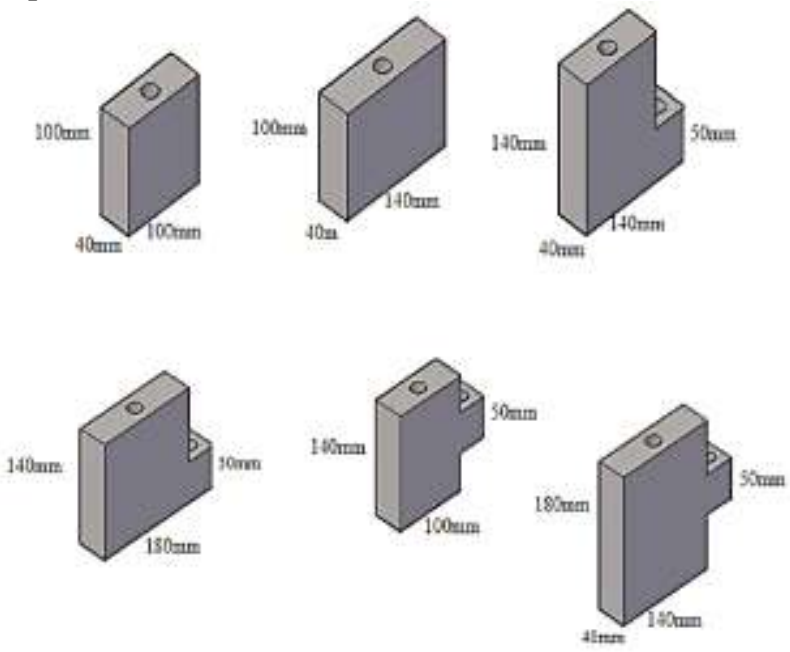

Figure 2: Specimens shapes and size

\subsection{Preparation}

The Formwork is a wooden molding and the blocks are reinforced with $\varnothing 5.061 \mathrm{~mm}$ steel bars. The metal pipes voids are fixed in place to slot the bolt of post-tension applications and also to clamp the block with one another. Figure 3 show the placement of reinforcement and the metal pipes void in the mould before concrete casting. 


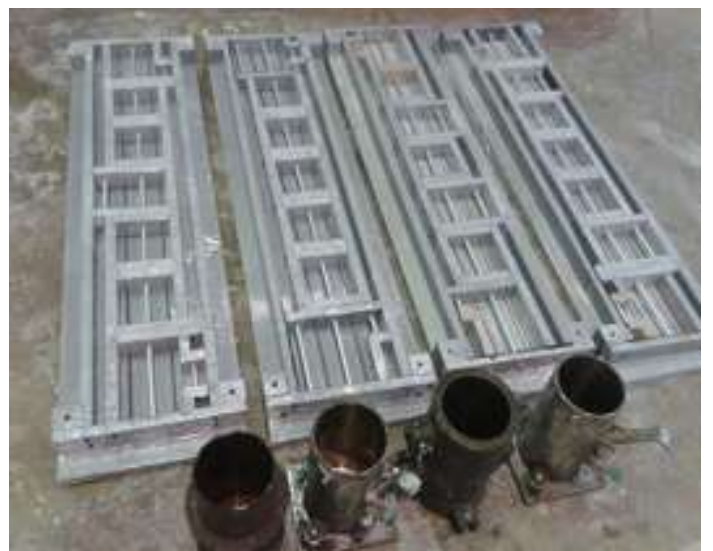

Figure 3: Formwork and Reinforcement Preparation

\subsection{Casting of IBS Block}

After all the reinforcement has been prepared and pipe fixed in place, casting of concrete was carried out. Castings were carried out in one concrete mix batches. The concrete mix is self-compact concrete with little compaction needed and 4 cylinder specimens were prepared for each batch for concrete characteristic strength. Curing was achieved by covering the concrete with a wet hessian to avoid concrete shrinkages.

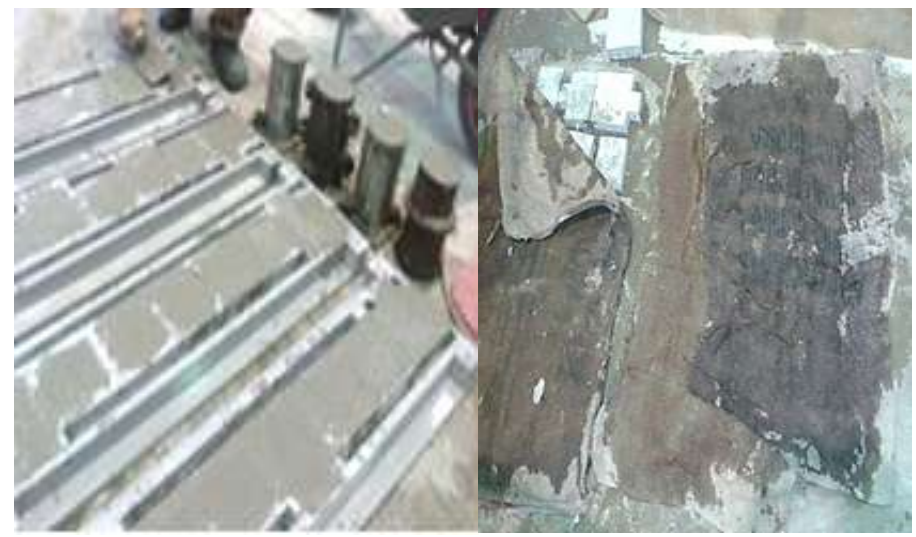

Figure 4: Casting and curing works

\subsection{Assembly of Columns Blocks}

The assembly process of the columns started after all casted blocks have reach specified strength and lightly painted. The connections between blocks by using clamping bolt and long nut through the middle and four sides voids of each column assembly as shown in Figure 5.
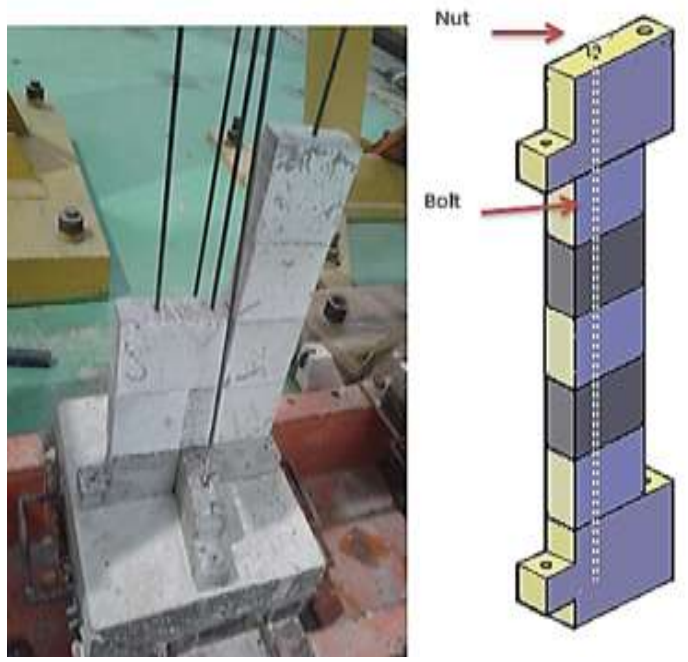

Figure 5: Assembly of Columns Blocks 


\subsection{Laboratory Experimental Setup}

The laboratory equipment's are set in order to perform a scaled experimental test. The main purpose of the test is to show real behavior of interlocking IBS block work columns system under lateral loads. The columns test was managed using hydraulic jack. The data logger used to record the incremental load and its effect on the strain of post-tension steel and displacement values.

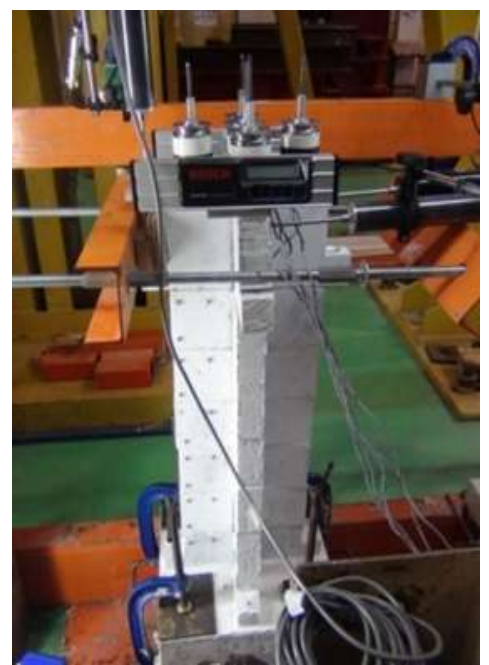

Figure 6: Static Load Test Setup

\subsection{Testing Arrangement and Instruction}

The columns are loaded in 4 laterals cyclic loads through the point load at column head at two different test directions. It will enable the calculation for lateral displacements at each layer of column are made as shown in Figure 7. The forces applied by the jack are measures using a load cell. The displacements are records by LVDT.

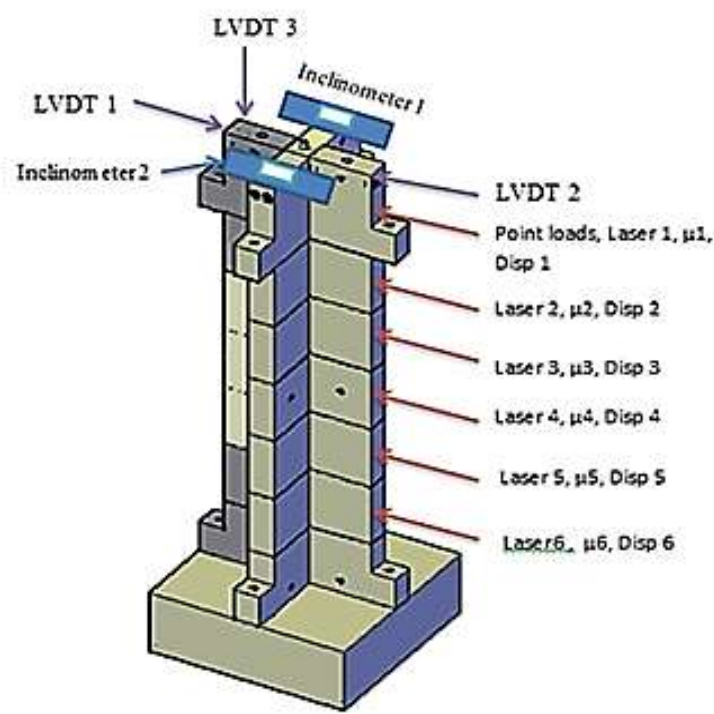

Figure 7: Testing Arrangement and Instruction

\section{Results And Discussion}

Columns behavior has been monitoring and recording throughout all four cycle of loads. The movements and lateral displacement of the columns was also recorded throughout the test and the load movements relationship will determined how the columns behaver.

\subsection{Columns behavior}

Columns behavior explained for two similar columns design but loaded in two different directions. It creates a different type of interlocking mechanism between the column blocks as shown in Figure 8a for Model 1 and Figure 8b for Model 2. 


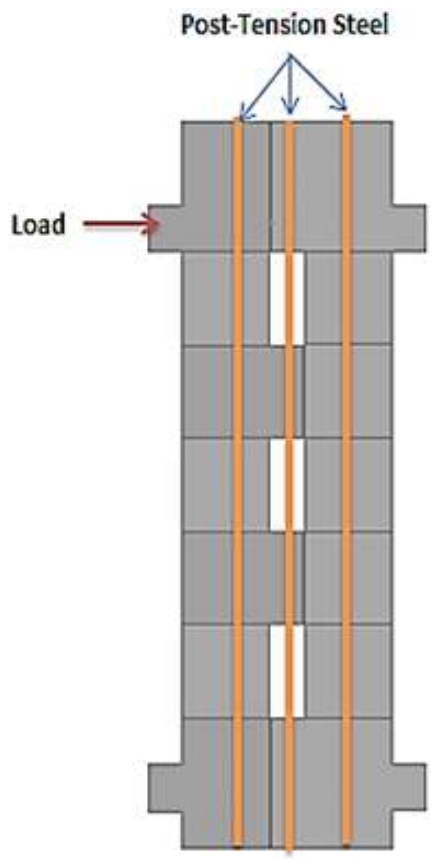

(a) Model 1

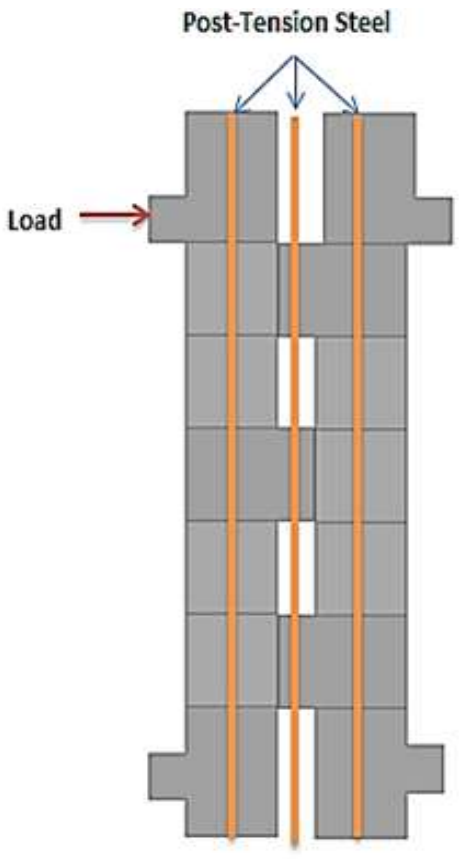

(b) Model 2

Figure 8: Blocks Interlocking due applied loads for Column Model 1 and Model 2.

\subsubsection{Column Model 1}

Column Model 1 was tested laterally from 0 to $4.1 \mathrm{KN}$ lateral loads in four cycles. Figures 9 and 10 show the acquired behavior of column Model 1 which is in cantilever mode of deflections.
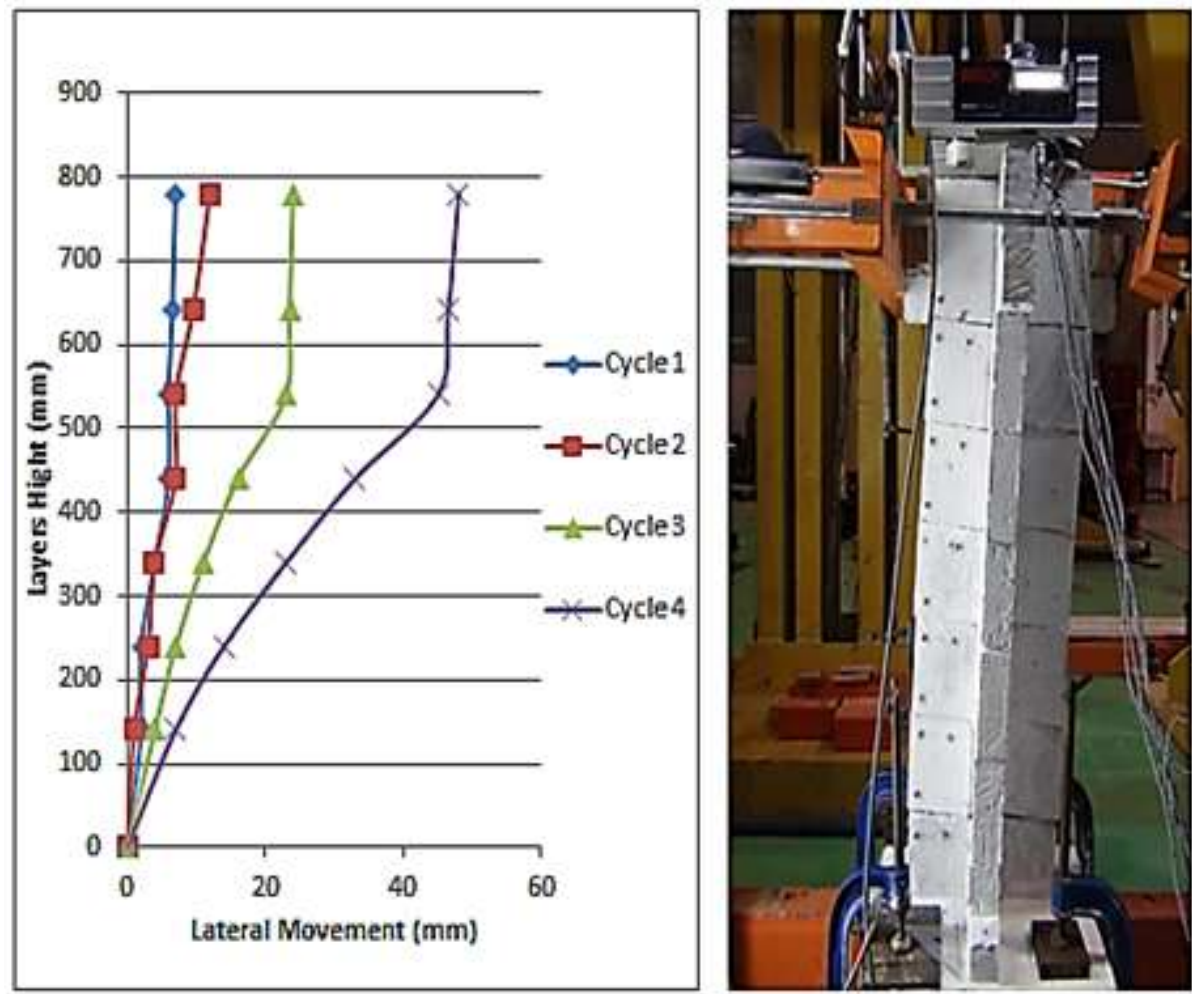

Figure 9: Height and Lateral Right Movement of Column Model 1

These cantilever action occurs at cycle 1 and 2 of $0.5 \mathrm{KN}$ and $0.6 \mathrm{KN}$ lateral loads. In cycle 3 and 4 of $1.9 \mathrm{KN}$ and $4.1 \mathrm{KN}$, the column blocks was deflection change to double curvature shapes, with the 1st curvature start from the base to level $540 \mathrm{~mm}$ and 2nd curvature start from level $540 \mathrm{~mm}$ until the end of column at level 780 $\mathrm{mm}$. 

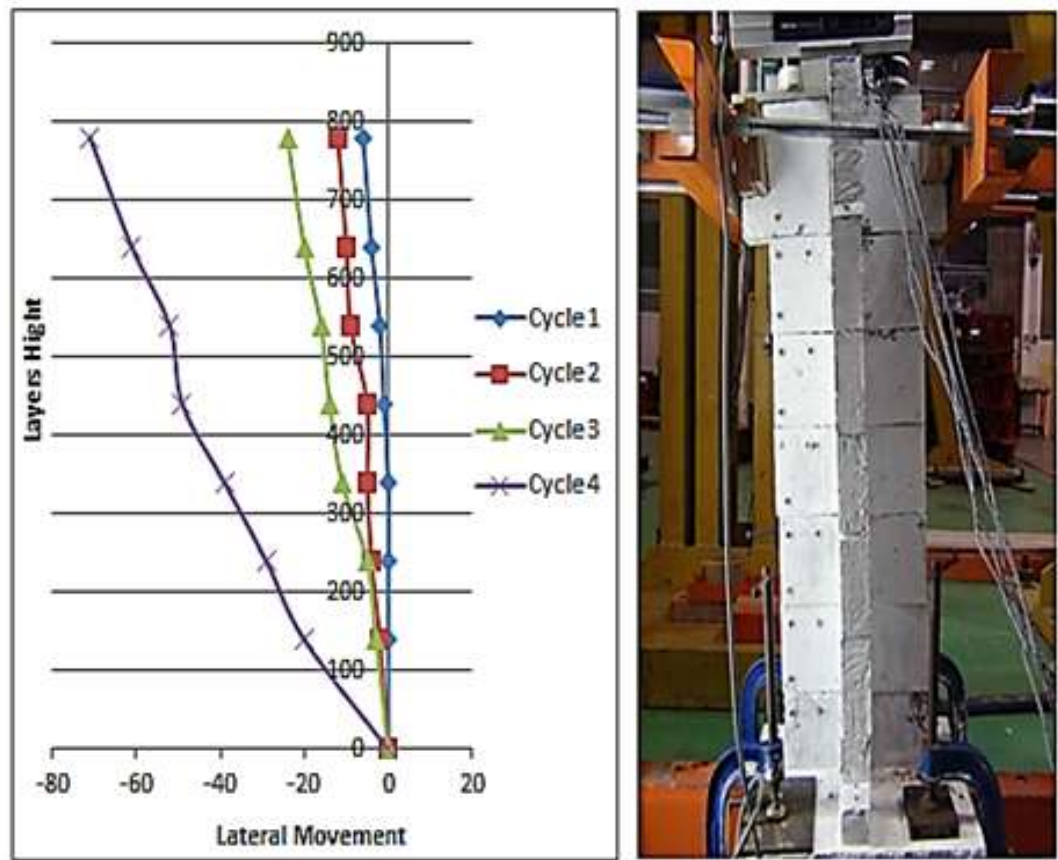

Figure 10: Height and Lateral Left Movement of Column Model 1.

From Figure 10 for left movement, it can be seen the column behavior as a cantilever at 4 cyclic loads. Lateral load values were $0.5 \mathrm{KN}$ of cycle $1,0.6 \mathrm{KN}$ of cycle $2,2 \mathrm{KN}$ of cycle 3 and $6.2 \mathrm{KN}$ ultimate load at cycle 4.

\subsubsection{Column Model 2}

Column Model 2 behavior was checked at two directions due to applied 4 cyclic loads at left and right direction after rotate it as shown in Figure $4.1 \mathrm{~b}$ as a 2 nd supposed test direction to check the effect of the interlocking of column blocks on the column behavior. Figures 11 and 12 show the acquired behavior of column Model 2.
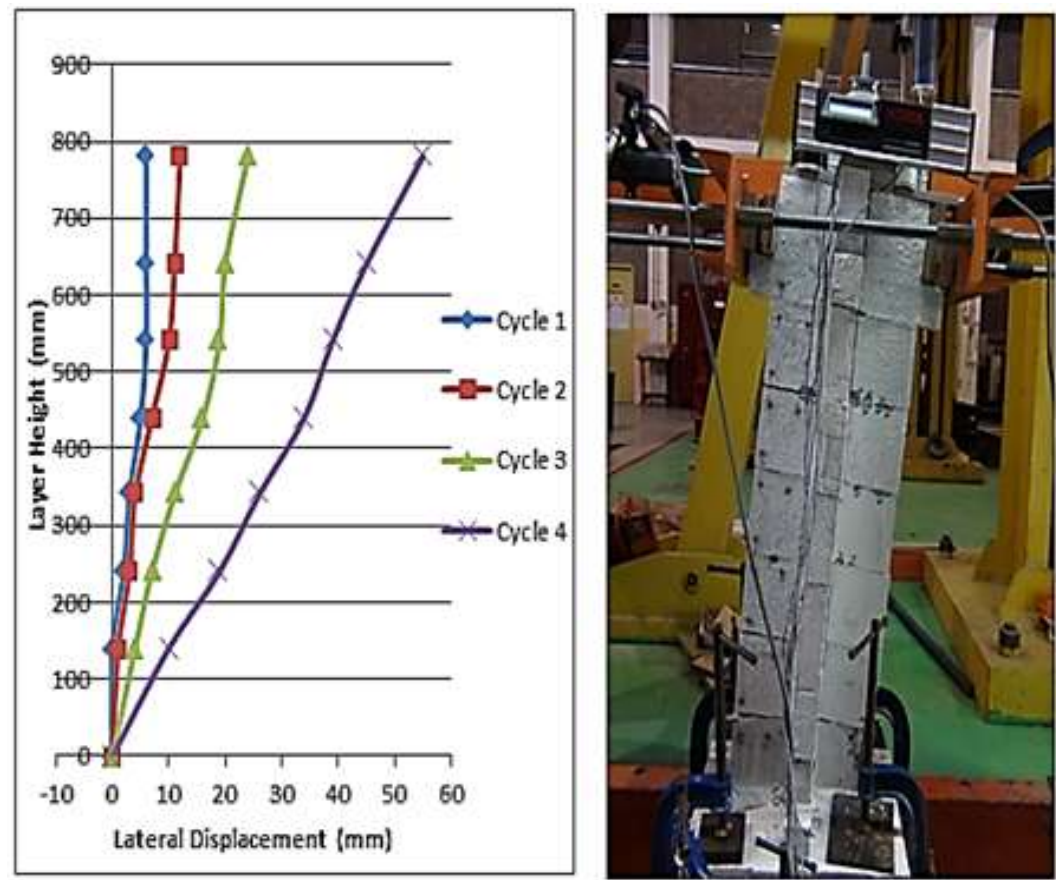

Figure 11: Height and Right Lateral Movement of Column Model 2

From Figure 11 for right movement, it can be seen the column behavior as a double curvature at cycle 1 and cycle 2 when the load was $1 \mathrm{KN}$ and $2.1 \mathrm{KN}$ and the behavior as a cantilever at cycle 3 and cycle 4 when the load was $3.2 \mathrm{KN}$ and at the ultimate load $5.8 \mathrm{KN}$. 

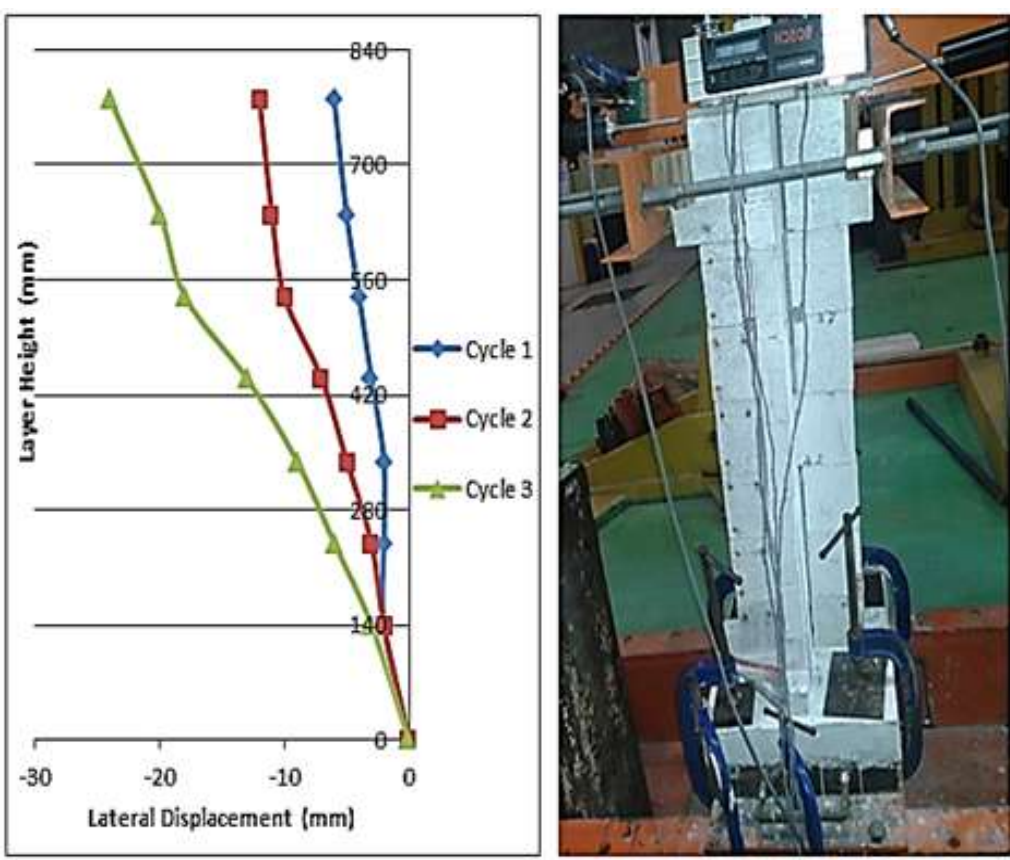

Figure 12: Layers Height versus Left Lateral Movement of Column Model 2

From Figure 4.5 for left movement, it can be seen the column behavior as a multi curvature at cycle 1 and double curvature at cycle 2 when the load was $1 \mathrm{KN}$ and $1.3 \mathrm{KN}$ and the behavior as a cantilever at cycle 3 at the load $2 \mathrm{KN}$. The behavior was check until cycle 3 only at left movement because the failure mode was at right direction in cycle 4 and not reached to ultimate load at left movement.

\subsection{Failure Mode}

Failure Mode was checked for two models in order to know the effect of blocks interlocking on the columns behavior to choose the correct direction of column set inside the structures.

\subsubsection{Failure Mode of Model 1}

Failure mode of the column Model 1 were observed at $6.2 \mathrm{KN}$ load at cycle 4 towards left direction. The column was fail due crushing 3rd block at $5.4 \mathrm{KN}$ load and crushed 4th and last block at the ultimate load $6.2 \mathrm{KN}$ as shown in Figure 13.

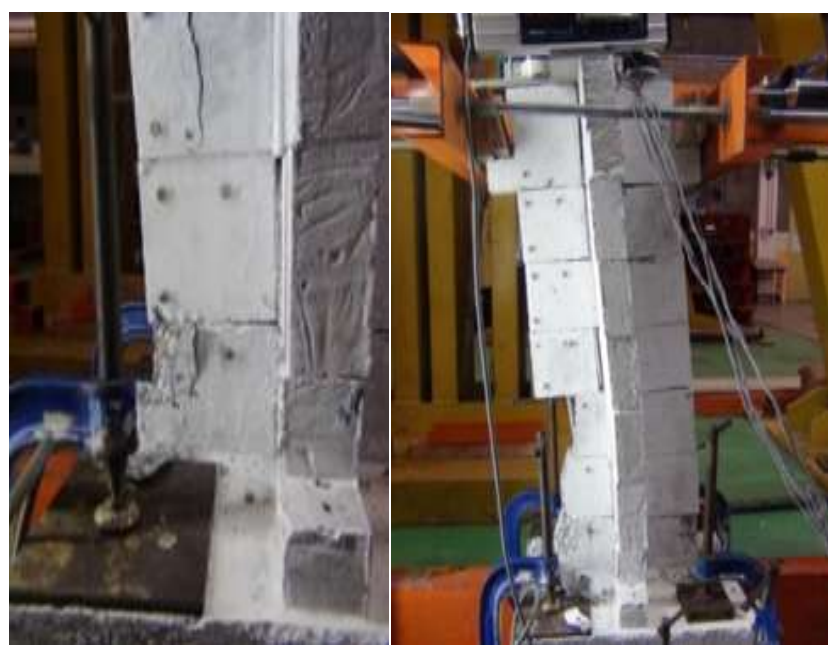

(a) Crushing at 3rd Block. (b) Crushed 4th and Last Block

Figure 13: Crushed 3rd, 4th and Last Block of Model 1.

\subsubsection{Failure Mode of Model 2}

The failure mode of the column Model 2 were observed at $5.8 \mathrm{KN}$ load at cycle 4 in right direction. The column was fail due to crushed at 3rd, 4th and last block at the ultimate load 5.8 KN as shown in Figure 14 . 


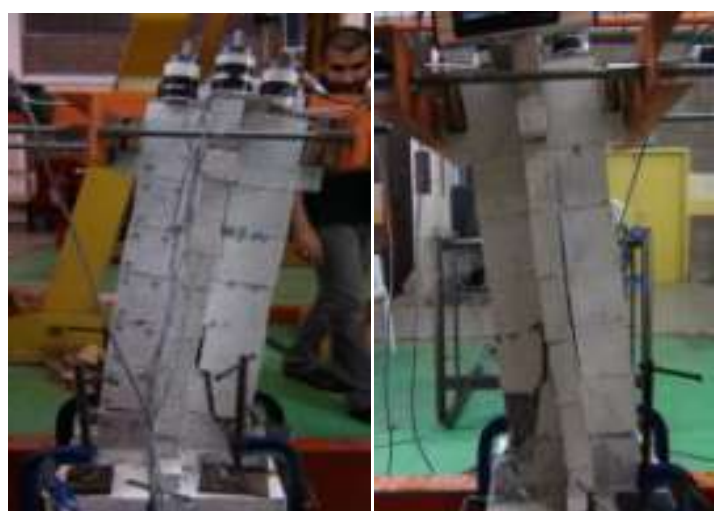

Figure 14: Crushed at 3rd, 4th Blocks and of Last Block In front and Rear View of Model 2 Failure

\subsection{Summary of Test Result Analysis}

Test result analysis and comparison of Model 1 and Model 2 mechanism is summarized in the Table 2.

Table 2 Comparison of Model 1 and Model 2 test results

\begin{tabular}{|l|l|}
\hline Model 1 & Model 2 \\
\hline Ultimate strength was $6.2 \mathrm{KN}$ & Ultimate strength was 5.8 KN \\
\hline Failure mode at left direction & Failure mode at right direction \\
\hline $\begin{array}{l}\text { Column behavior as a double curvature at right direction and } \\
\text { cantilever at left direction at the ultimate load. }\end{array}$ & $\begin{array}{l}\text { Column behavior as a cantilever at left and right } \\
\text { direction at the ultimate load. }\end{array}$ \\
\hline Maximum horizontal deflection $66.99 \mathrm{~mm}$ & Maximum horizontal deflection $55 \mathrm{~mm}$ \\
\hline Maximum vertical deflection $4.44 \mathrm{~mm}$ & Maximum vertical deflection $4.4 \mathrm{~mm}$ \\
\hline $\begin{array}{l}\text { Left direction column undergo strength mechanism with ductile } \\
\text { fracture at the base but at right direction undergo plastic hinges } \\
\text { mechanism with ductile fracture at the base and plastic hinges at and } \\
\text { ultimate load }\end{array}$ & $\begin{array}{l}\text { Left and right direction column undergo strength } \\
\text { mechanism with ductile fracture at the base at the } \\
\text { ultimate load }\end{array}$ \\
\hline
\end{tabular}

\section{Conclusion}

The dissertation has presented an investigation on IBS blockworks system of cantilever post-tension columns that have been fabricated and tested in the Structural and Material Laboratory of Faculty of Civil Engineering, University Technology of Malaysia (UTM). Based on the experimental test results, the main findings are highlighted and concluded as follow:

1. Lateral load and lateral blocks movement was estimated through the test and calculations.

2. Columns behavior at two deferent test directions and effect of column blocks interlocking on the columns behavior was a cantilever action at cycle 1 and 2 and the deflection change to double curvature at cycle 3 and 4 at right movement and cantilever at 4 cyclic loads at left movement of Model 1. The column behavior as a double curvature at cycle 1 and cycle 2 and as a cantilever at cycle 3 and cycle 4 at right movement and as a multi curvature at cycle 1 and double curvature at cycle 2 and the behavior as a cantilever at cycle 3 at left movement of Model 2.

3. Ultimate strength of the structure is $6.2 \mathrm{KN}$ for column Model 1 and $5.8 \mathrm{KN}$ for column Model 2 and the failure is characterized by crushing and spalling of concrete of both Models.

4. Columns behavior from two tests has identified which direction should the column be arrange to form the uniformly distributed strength inside the structural system.

\section{References}

[1] Blismas, N., Wakefield, R., \& Hauser, B. 2010. Concrete prefabricated housing via advances in systems technologies: Development of a technology roadmap. Engineering, Construction and Architectural Management. 17(1): 99-110.

[2] Hamid, Z. A., Kamar, K. A. M., Alshawi, M., Zain, M. Z. M., Ghani, M. K., and Rahim, A. H. A. 2008. Industrialized Building System (IBS) Construction Supply-Chain Strategies of Malaysian Contractors. 2 (1): 1-13.

[3] CIDB.September 2007. IBS Digest at Malbex. BS Digest, Special Issues on 24th Malaysian International Building Exposition.1922 .

[4] Tam, C. M., Deng, Z. M., and Zeng, S. X. 2002. Evaluation of Construction Methods and Performance for High Rise Public Housing Construction in Hong Kong.Building and Environment. 37(10): 983-991.

[5] Zahn, F. A., \& GANZ, H. R. 1992. Post-tensioned in buildings. VSL Report Series, 4.

[6] ParthaPratim Roy, B. E., Prestressed Concrete in Building: Advantages and Economics. ADAPT International Pvt. Ltd. http://www.nbmcw.com/articles/concrete/others/491-prestressed-concrete-in-building-advantages-and-economics.html (Accessed on 15 March 2011)

[7] Marsono, A. K., Malaysia, U. T. 2012. Experimental of industrialised building system blockwork for housing.

[8] Eurocode 2. 2004. Design of Concrete Structure-Part 1-1: General Rules and Rules for Buildings. (EN 1992-1-1:2004), European Committee for Standardization, Management centre, 36 B-1050 Brussels.

[9] BaderulHisham, M.Z. \&Marsono, A.K. 2013.Friction Mechanism in IBS Blockwork Column.University Technology of Malaysia.33-47. 